\title{
Effects of flutamide on testicular involution induced by an antagonist of gonadotrophin-releasing hormone and on stimulation of spermatogenesis by follicle-stimulating hormone in rats
}

\author{
R. K. Chandolia, G. F. Weinbauer, U. Fingscheidt, J. M. S. Bartlett and \\ E. Nieschlag*
}

Institute of Reproductive Medicine of the University, D-4400 Münster, German Federal Republic

\begin{abstract}
Summary. The effects of combined treatment with an antagonist of gonadotrophinreleasing hormone (ANT) and the antiandrogen flutamide (FL) on spermatogenesis were studied in the presence and absence of exogenous follicle-stimulating hormone (FSH). After treatment for 2 weeks, the combination of ANT (RS 68439, 450-500 $\mu \mathrm{g}$ / $\mathrm{kg}$ per day, s.c.) with 10,20 or $40 \mathrm{mg}$ FL/day, s.c. was as effective as ANT plus the Leydig cell toxin ethane dimethane sulphonate $(75 \mathrm{mg} / \mathrm{kg}$ per week, i.p.) in terms of reduction in weight of testes, epididymides and seminal vesicles. Thus, a daily dose of $10 \mathrm{mg} \mathrm{FL} / \mathrm{kg}$ was sufficient to block the androgen action in the testes of ANT-treated rats. In a second experiment, rats received ANT and ANT $+F L(10 \mathrm{mg} / \mathrm{kg})$ alone or in combination with a highly purified human FSH preparation ( 5 or $10 \mathrm{iu}$, twice a day) for 2 weeks. FSH did not affect testosterone concentration or weight of epididymides and seminal vesicles, but ANT + FL markedly enhanced the ANT-induced reduction of testis weight, seminiferous tubule diameter and numbers of germ cells, as revealed by qualitative and quantitative analysis of testis histology. In the absence of FL, testis size and numbers of germ cells, including elongated spermatids, were increased by FSH. In the presence of FL, the effects of FSH were less pronounced with respect to the germ cells, in terms of both numbers of cells and the effective dose of FSH. Irrespective of treatment with FL, exogenous FSH increased the inhibin concentrations in serum, indicating that Sertoli cells remained responsive to FSH. From the present study it is concluded that (i) FL accelerates ANT-induced testicular involution, (ii) FSH has a role in adult spermatogenesis and (iii) the effects of FSH on advanced germ cells are influenced by androgens.
\end{abstract}

Keywords: FSH; spermatogenesis; GnRH antagonist; antiandrogen; rat

\section{Introduction}

Disruption of spermatogenesis and pronounced reduction of testosterone production occur in gonadotrophin-suppressed rats after treatment with an antagonist (ANT) of gonadotrophinreleasing hormone (GnRH) (Huhtaniemi et al., 1984; Rea et al., 1986) or hypophysectomy (Buhl $e t$ al., 1982; Huang et al., 1987; Bartlett et al., 1989). In these animals, however, the germinal epithelium still contains pachytene spermatocytes and round spermatids. Step VII spermatids, although less frequent, were observed up to 61 days after hypophysectomy (Clermont \& Morgentaler, 1955). Since, under these experimental conditions, androgen production is not totally

*Author for correspondence. 
inhibited, low residual concentrations of testosterone may be involved in the partial maintenance of germ cell development, This assumption is supported by marked enhancement of testicular involution and loss of germ cells in hypophysectomized and ANT-treated rats by removal of Leydig cells by ethane dimethane sulphonate (EDS) (Teerds et al., 1988; Weinbauer et al., 1989a).

Although earlier investigations did not reveal a role for FSH in spermatogenesis in adults rats (Dym et al., 1979), several recent studies demonstrated that a highly purified human FSH preparation, alone or in combination with testosterone, stimulates maintenance of germ cells in hypophysectomized (Bartlett et al., 1989; Toppari et al., 1989) and ANT-treated rats (Weinbauer $e t$ al., 1989a). In these studies, the effects of FSH were more pronounced in the presence of testosterone, suggesting that the action of FSH is influenced by the presence of Leydig cells and/or testosterone. The present study investigated, in ANT-treated rats, whether (i) blockade of testosterone action by a nonsteroidal, pure antiandrogen, flutamide (FL; Neumann \& Töpert, 1986), enhances testicular involution and (ii) the stimulation by FSH occurs in the presence of an antiandrogen.

\section{Materials and Methods}

Animals. Adult male Sprague-Dawley rats weighing 400-450 g were housed in groups of 2-3 under controlled temperature and a $12 \mathrm{~h} \mathrm{light,} 12 \mathrm{~h}$ dark cycle, with rat chow and tap water ad libitum. Handling and treatment of the experimental animals were performed according to the Regulations of the German Federal Law on the Care and Use of Laboratory Animals.

Compounds and application. The GnRH antagonist [ $N$-Ac-D-Nal $(2)^{1}$, D-pCl-Phe $\left.{ }^{2}, \mathrm{D}-\mathrm{Trp}^{3}, \mathrm{D}-\mathrm{hArg}(\mathrm{Et} 2)^{6}, \mathrm{D}-\mathrm{Ala}{ }^{10}\right]-$ GnRH (RS 68439: Syntex Research, Palo Alto, CA, USA) was dissolved in the vehicle propylene glycol:water $(1: 1$, $\mathrm{v} / \mathrm{v}$ ) and given at a daily dose of $450-500 \mu \mathrm{g} / \mathrm{kg}$. This dose of ANT, which suppressed serum concentrations of LH, FSH and testosterone to undetectable levels within 7 days (Chandolia et al., 1991), was chosen to ensure thorough inhibition of hormone secretion in the present study. Flutamide (4-nitro-3-trifluoromethyl-isobutyranilide; Schering Corp., Bloomfield, NJ, USA) was dissolved in sesame oil:ethanol $(1: 1, \mathrm{v} / \mathrm{v})$ and administered subcutaneously at 10,20 or $40 \mathrm{mg} / \mathrm{kg}$ body weight. Vehicle, ANT and FL were injected subcutaneously in $0.2 \mathrm{ml}$. A highly purified human FSH preparation (Fertinorm: Serono, Freiburg, Germany) was injected subcutaneously twice a day at 5 or $10 \mathrm{iu} / \mathrm{rat}$ in $100 \mu \mathrm{l}$. This FSH preparation contained $<\mathbf{0 . 0 0 8}$ iu luteinizing hormone (LH)/vial (Harlin et al., 1986) and did not stimulate testosterone production by Leydig cells (Sharpe \& Bartlett, 1985). Ethane dimethane sulphonate (EDS) was dissolved in dimethylsulphoxide:water $(1: 3, \mathrm{v} / \mathrm{v})$ and injected once intraperitoneally at $75 \mathrm{mg} / \mathrm{kg}$ body wt.

Experimental protocol. Experiment 1 was carried out to identify an active dose of FL. Seven groups, of 8 rats each, were assigned to the following 7 treatments for 14 days: vehicle, $10 \mathrm{mg} \mathrm{FL} / \mathrm{kg}$, ANT, ANT + $10 \mathrm{mg} \mathrm{FL} / \mathrm{kg}$, ANT $+20 \mathrm{mg} \mathrm{FL} / \mathrm{kg}$, ANT + $40 \mathrm{mg} \mathrm{FL} / \mathrm{mg}$ and ANT + EDS.

In Expt 2, seven groups, of 7 rats each, received the following 7 treatments for 14 days: vehicle, ANT, ANT + $10 \mathrm{mg} \mathrm{FL} / \mathrm{kg}$, ANT + FSH1 $(2 \times 5 \mathrm{iu})$, ANT + FSH2 $(2 \times 10 \mathrm{iu}) ;$ ANT + FL + FSH1 $(2 \times 5 \mathrm{iu})$; and ANT + FL + FSH2 $(2 \times 10 \mathrm{iu})$.

On Day 15, both experiments ended. The animals were sedated with carbon dioxide and decapitated. Trunk blood was collected for determination of concentrations of $\mathrm{LH}, \mathrm{FSH}$, testosterone and inhibin. The testes, epididymides and seminal vesicles (including the coagulating glands) were excised and weighed. One testis was immersed in liquid nitrogen immediately after weighing and then preserved at $-80^{\circ} \mathrm{C}$ till used for measurement of testosterone concentrations; the other testis was fixed in Bouin's solution for histological examination.

Hormone assays. Serum testosterone concentrations were measured by radioimmunoassay (RIA) as described by Schürmeyer et al. (1983). For intratesticular testosterone, the testis was homogenized in phosphate buffer $(1 \mathrm{~g} / 2 \mathrm{ml})$ and RIA was performed after ether extraction (Nieschlag et al., 1975) without further chromatography. Serum rat LH (rLH) and rFSH were measured by double-antibody RIA with reagents supplied by NIADDK (Bethesda, MD, USA). The standard preparations used were LH-RP-1 and FSH-RP-2, tracers were prepared from LH-I-6 and FSHI-6 and the antisera were anti-rLH-S-9 and anti-rFSH-S-11. Each hormone was analysed in a single assay. The detection limit for both assays was $1.6 \mathrm{ng} / \mathrm{ml}$ and the intra-assay coefficient of variation was 3.5 and $2.8 \%$ for $\mathrm{LH}$ and FSH, respectively. Inhibin was measured in a double-antibody RIA as described for male rats (Robertson et al., 1988). This assay used an antiserum raised in rabbits against highly purified bovine $31 \mathrm{kDa}$ inhibin using the standard described by Fingscheidt $e t$ al. (1989). The intra-assay and interassay variation was 3.5 and $4.5 \%$, respectively. The detection limit of inhibin was $270 \mathrm{U} / \mathrm{l}$. The hFSH concentrations were also measured (Bartlett et al., 1989) using a human FSH fluorescence-immunoassay kit (Wallac, Turku, Finland) for which the intra- and interassay variations were $2 \cdot 7$ and $7 \%$, respectively.

Testicular histology. Testes were dehydrated and embedded in historesin (2218-500 kit, LKB, Bromma, Sweden) and stained with periodic acid-Schiff's reagent and haematoxylin. Germ cells were counted in stage VII seminiferous 
tubules (Leblond \& Clermont, 1952) in all groups in Expt 2 and in the group in Expt 1 treated with $10 \mathrm{mg} \mathrm{FL} / \mathrm{kg}$. Testes at this stage contain representative germ cells (A-spermatogonia, preleptotene and pachytene spermatocytes and step 7 round and step 19 elongated spermatids) and are particularly sensitive to hormone deprivation (Russell \& Clermont, 1977). Thirty tubules were counted per animal. The cell counts were corrected for section thickness (Abercrombie, 1946) and for tubular shrinkage on the basis of Sertoli cell counts.

Statistical analysis. Data were analysed using one-way analysis of variance and Tukey's test to determine significant differences at the $5 \%$ level. Data are expressed as means \pm s.e.m.

\section{Results}

\section{Experiment 1}

FL alone had no effect on testis weight, but significantly $(P<0.05)$ reduced the weights of the epididymides and seminal vesicles (Fig. 1). After ANT administration, the weight of all organs was markedly reduced. With ANT, testicular weight was reduced to $1.10 \pm 0.04 \mathrm{~g}$ compared with $2.05 \pm 0.05 \mathrm{~g}$ in the vehicle-treated group. The addition of FL or EDS reduced testis weights further to $0.68 \pm 0.02 \mathrm{~g}$ and $0.65 \pm 0.03 \mathrm{~g}$, respectively, compared with ANT alone $(P<0.05)$. All 3 doses of FL in combination with ANT had an effect on testis size similar to treatment with EDS $(P>0.05)$. The weights of the epididymides and seminal vesicles were similar in all groups receiving ANT with FL or EDS.

These results indicate that the lower dose of FL $(10 \mathrm{mg} / \mathrm{kg})$ was sufficient to block fully the action of testosterone: hence, this dose was used in Expt 2. In Expt 1, analysis of hormones and testicular histology was only performed in the group treated with FL alone.

\section{Experiment 2}

Organ weights. As in Expt 1 , ANT reduced testis weight by $\sim 50 \%$ compared with vehicle administration (Fig. 2a); FL reduced testicular weight further to $0.72 \pm 0.01 \mathrm{~g}$ compared with $1.09 \pm 0.05 \mathrm{~g}$ in the ANT group $(P<0.05)$. Both doses of FSH exerted similar stimulation $(P<0.05)$ on testis weight in the ANT + FSH groups $(1.32 \pm 0.03$ and $1.38 \pm 0.04 \mathrm{~g}$, respectively). In the presence of FL, however, the lower dose of FSH $(2 \times 5 \mathrm{iu})$ was ineffective $(P>0.05)$ compared with ANT + FL treatment, whilst the higher dose of FSH $(2 \times 10 \mathrm{iu})$ produced a significant effect. The weights of seminal vesicle plus coagulating gland (Fig. 2b) were similar in all treated groups. Epididymis weights (Fig. 2c) were slightly, but not significantly, reduced by FL.

Diameter of seminiferous tubules. The diameter (Fig. 2d) was significantly $(P<0.05)$ lower in the ANT-treated group than in controls and was further reduced $(P<0.05)$ by the addition of FL. Only the higher dose of FSH significantly increased tubule diameter. The diameter of seminiferous tubules after treatment with $F L$ alone $(383.95 \pm 6.95 \mu \mathrm{m})$ was not significantly different from controls $(369.67 \pm 6.07 \mu \mathrm{m})$.

Hormone concentrations. In the group treated with FL alone, serum testosterone concentrations were approximately 9 times higher than in the control (Table 1). The intratesticular testosterone concentrations were 10 times higher $(7 \cdot 12 \pm 0.67 \mathrm{nmol} / \mathrm{g}$ testis $)$ than the control values $(0.67 \pm 0.07 \mathrm{nmol} / \mathrm{g}$ testis). In ANT and ANT + FL groups, the testosterone concentrations remained below the detection limit of the assay. Supplementation with FSH did not alter concentrations of testosterone either in ANT or ANT + FL groups, which remained below the detection limit of the assay. Serum LH concentrations in the FL group were about 8 times higher than control values, but, in all treated groups in Expt 2, LH concentration remained below the detection limit of the assay.

Serum FSH concentrations were twice as high in the FL group as in the control, but remained below the detection limit of the assay in ANT and ANT + FL groups. Supplementation of hFSH in these groups (ANT and ANT + FL) led to a dose-dependent increase in serum hFSH concentrations. The rFSH concentrations were detectable in ANT + FSH groups, since hFSH cross- 

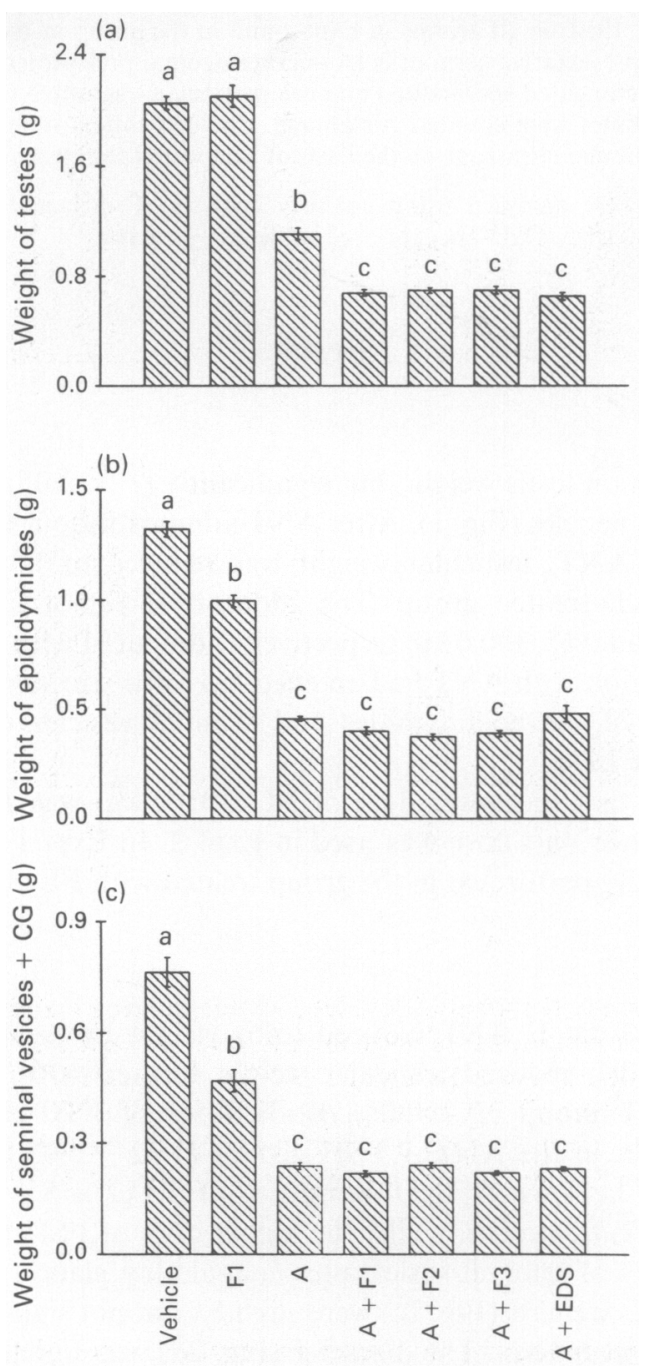

Fig. 1. Weights of (a) testes, (b) epididymides and (c) seminal vesicles plus coagulating glands (CG) in rats after 2 weeks of treatment with vehicle, gonadotrophin-releasing hormone antagonist (ANT) and flutamide (FL). F1, F2 and F3 $=10,20$ or $40 \mathrm{mg} \mathrm{FL} / \mathrm{kg}$ per day, respectively; $\mathrm{A}=450-500 \mu \mathrm{g} \mathrm{ANT} / \mathrm{kg} / \mathrm{rat}$ per day; EDS = single injection of $75 \mathrm{mg}$ ethane dimethane sulphonate $/ \mathrm{kg}$. Values represent means \pm s.e.m. of 8 rats/group. Unlike letters indicate significant difference at $P<0.05$ (ANOva followed by Tukey's test).

reacts with the rFSH antiserum (Bartlett et al., 1989). The inhibin concentrations in ANT, ANT + FSH1 and ANT + FL groups were significantly $(P<0.05)$ lower than in the control group. In other groups in Expt 2, the inhibin concentrations were in the control range. In the group treated with FL alone, inhibin concentrations were significantly $(P<0.05)$ higher than in the control.

\section{Testicular histology}

Qualitative analysis. Control testes showed normal testicular morphology and intact spermatogenesis. After ANT treatment, there were fewer or no elongated spermatids. Degenerating cells, 

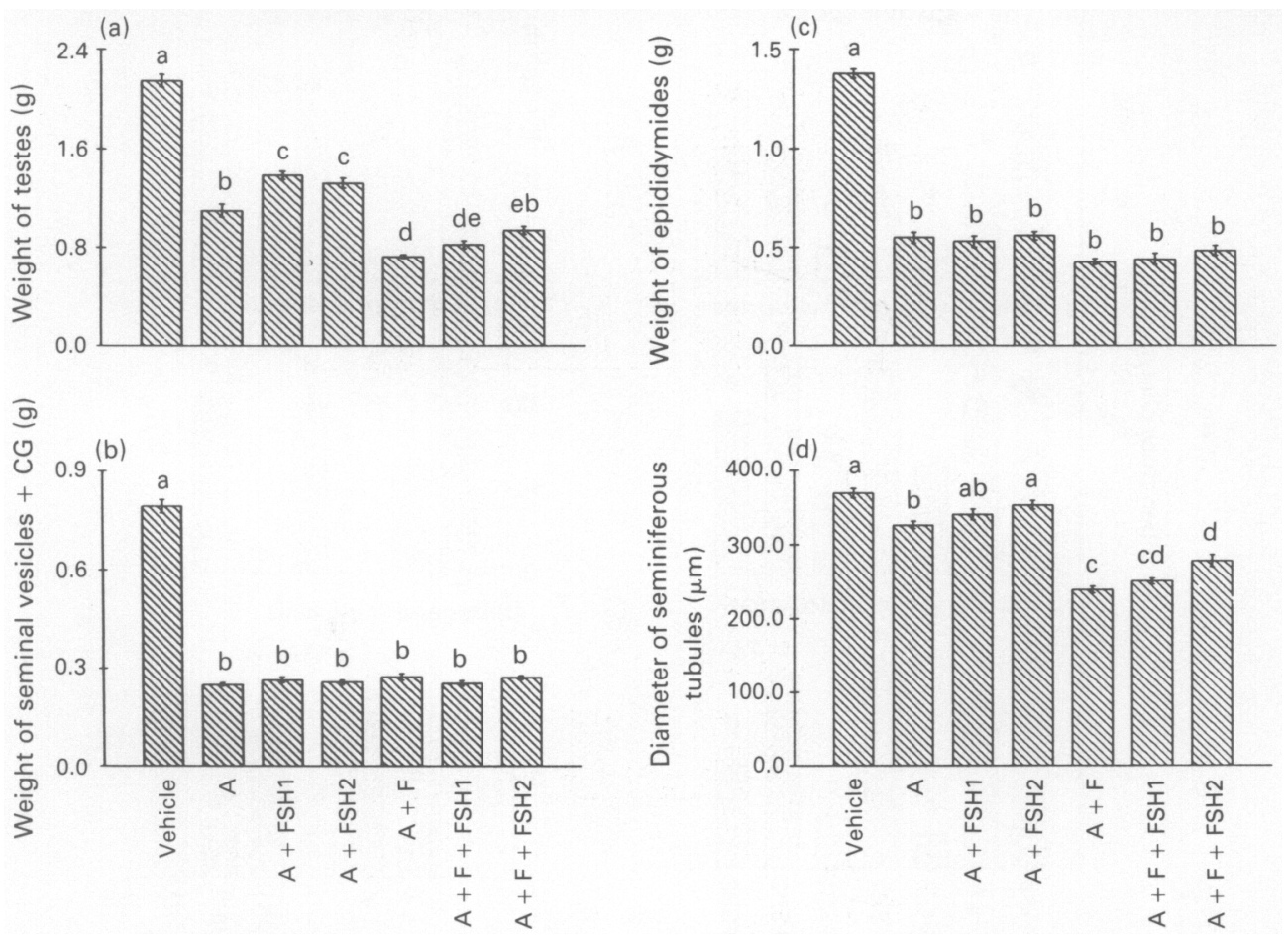

Fig. 2. Weights of (a) testes, (b) seminal vesicles plus coagulating glands (CG), (c) epididymides and (d) diameter of seminiferous tubules in rats after 2 weeks of treatment with vehicle, gonadotrophin-releasing hormone antagonist (ANT), flutamide (FL) and follicle-stimulating hormone (FSH). $\mathrm{F}=10 \mathrm{mg} \mathrm{FL} / \mathrm{kg}$ per day; $\mathrm{A}=450-500 \mu \mathrm{g} \mathrm{ANT} / \mathrm{kg} / \mathrm{rat}$ per day; FSHl and FSH $2=2 \times 5$ and $2 \times 10$ iu FSH/rat per day, respectively. Values represent means \pm s.e.m. of $7 \mathrm{rats} /$ group. Unlike letters indicate significant difference at $P<0.05$ (ANOVA followed by Tukey's test).

identified as pachytene spermatocytes or round spermatids, were observed. FL markedly aggravated testicular involution. No elongated spermatids were encountered, but degenerating cells were frequent. After supplementation with FSH at either dose, in the absence of FL, spermatogenesis was indistinguishable from the control, except that some degenerating germ cells were seen. In the presence of FL, however, elongated spermatids were not found in the group receiving the lower dose of FSH and were rare after administration of the higher FSH dose.

Quantitative analysis. There were slightly, but not significantly, fewer A-spermatogonia in the ANT-treated group than in the control (Fig. 3). The addition of FL induced a significant $(P<0.05)$ reduction in numbers of spermatogonia. With the lower dose of FSH, no clear-cut effects occurred, but the higher dose of FSH maintained the number of A-spermatogonia within the control range. Preleptotene spermatocytes were significantly $(P<0.05)$ less frequent in ANT + FL and ANT + FL + FSH1 groups than in the controls. In all other groups the numbers of preleptotene spermatocytes did not differ from the controls.

After administration of ANT alone, the numbers of pachytene spermatocytes and round and elongated spermatids were reduced to 65,50 and $40 \%$, respectively, of those in the control group $(P<0.05)$. The combination of ANT and FL further reduced the number of pachytene spermatocytes and round spermatids from $6.87 \pm 0.30$ to $1.72 \pm 0.34$ and from $22.65 \pm 1.53$ to $5.46 \pm 0.54$, respectively $(P<0.05)$, compared with ANT alone. Elongated spermatids were absent. 

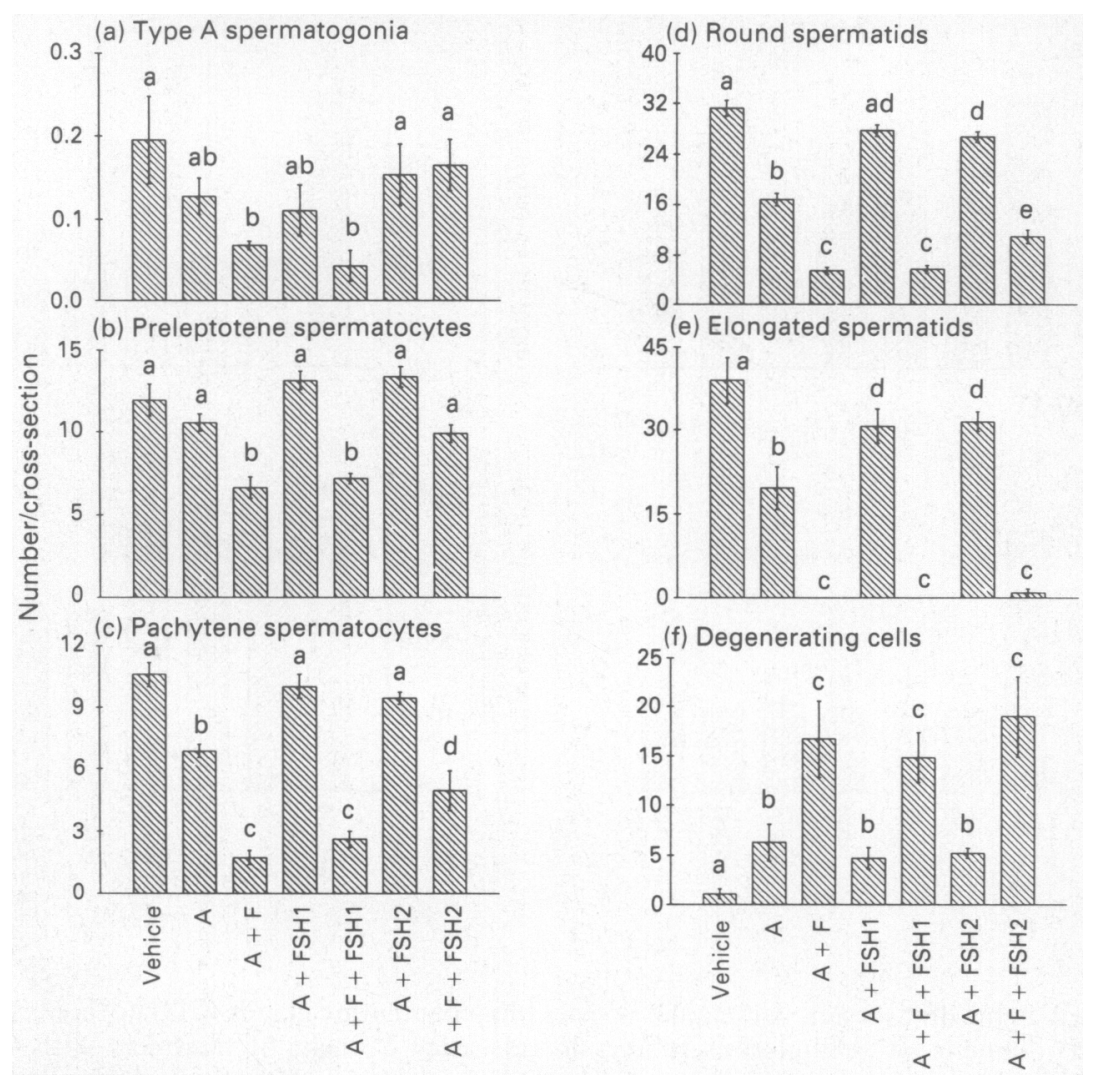

Fig. 3. Number of germ cells/seminiferous tubule cross-section in stage VII of the spermatogenic cycle in rats: (a) type A spermatogonia, (b) preleptotene and (c) pachytene spermatocytes, (d) round (step 7) and (e) elongated spermatids (step 19) and (f) degenerating cells after 2 weeks of treatment with vehicle, gonadotrophin-releasing hormone antagonist (ANT), flutamide (FL) and follicle-stimulating hormone (FSH). $\mathrm{F}=10 \mathrm{mg} \mathrm{FL} / \mathrm{kg}$ per day; $\mathrm{A}=450-500 \mu \mathrm{g} \mathrm{ANT} / \mathrm{kg} /$ rat per day; FSH1 and FSH2 $=2 \times 5$ and $2 \times 10 \mathrm{iu}$ FSH/rat per day, respectively. Values represent means \pm s.e.m. of 7 rats/group. Unlike letters indicate significant difference at $P<0.05$ (ANOVA followed by Tukey's test). Degenerating cells are expressed as percentage of the number of pachytene spermatocytes and round spermatids.

In the absence of FL, both doses of FSH maintained the numbers of pachytene spermatocytes and round spermatids within or close to the control range. The numbers of elongated spermatids also increased significantly $(P<0.05)$. In the presence of FL, the lower dose of FSH had no significant influence on the number of pachytene spermatocytes and spermatids. The higher dose of FSH raised $(P<0.05)$ the numbers of pachytene spermatocytes and round spermatids and exerted a marginal effect on numbers of elongated spermatids in 2 animals only $(1.25$ and 5.03 cells/crosssection).

Absolute numbers of degenerating cells were higher in all treated animals than in vehicleinjected control animals. Based on their size and location in the seminiferous epithelium, these cells were identified as pachytene spermatocytes and round spermatids. Since the rate of disappearance of degenerating cells may differ in the various treatment groups, the number of these cells was expressed as a percentage of the total number of pachytene spermatocytes and round spermatids present. In the presence of FL, the frequency of degenerating cells increased about 3-fold compared with administration of ANT alone. FSH, irrespective of the presence of FL, had no discernible effect on numbers of degenerating cells. 

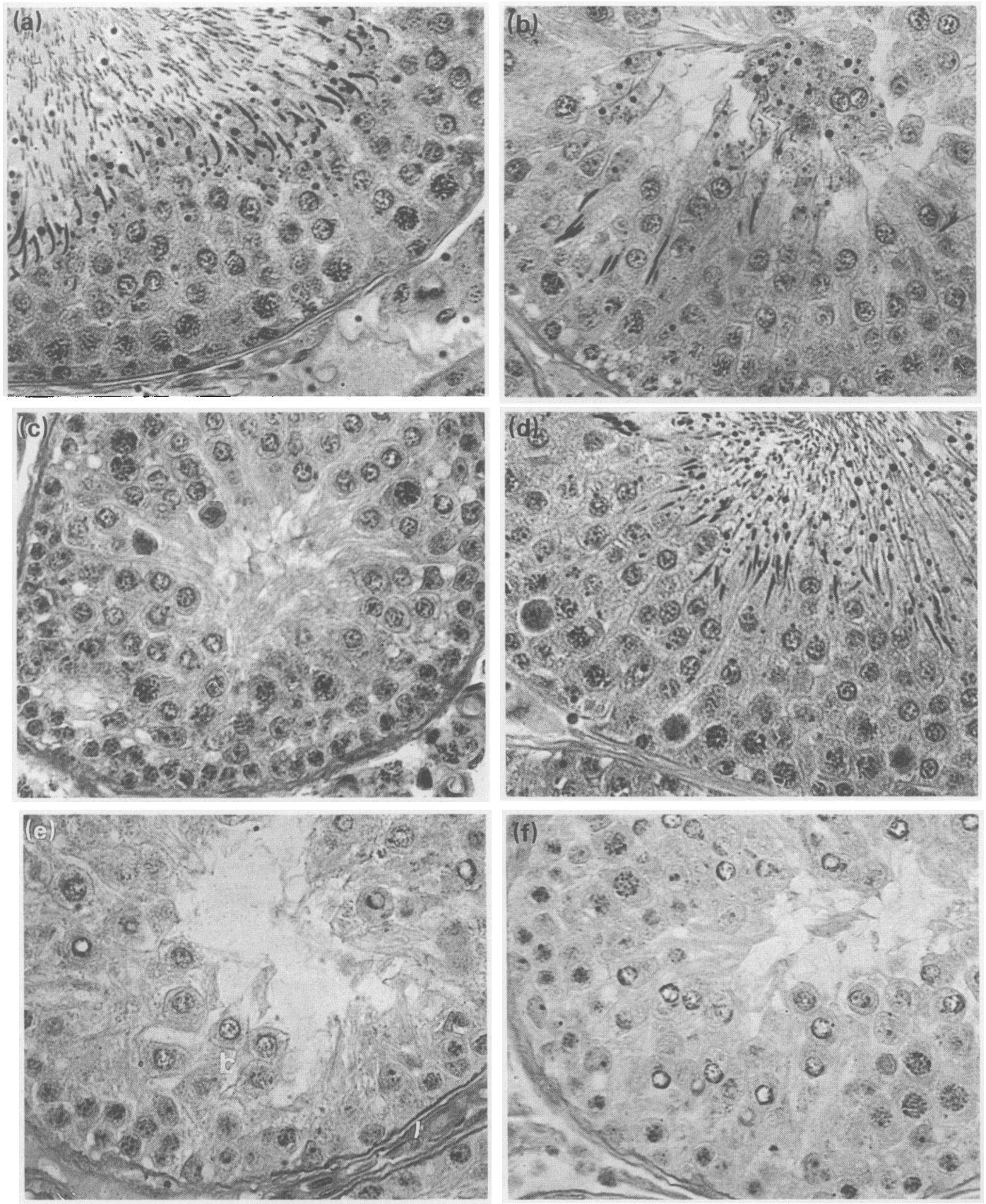

Fig. 4. Light micrographs of stage VII seminiferous tubule cross-section following 2 weeks of treatment with vehicle, gonadotrophin-releasing hormone antagonist (ANT), flutamide (FL) and follicle-stimulating hormone (FSH). (a) Vehicle: intact spermatogenesis; (b) ANT: reduced number of spermatids, few elongated spermatids, note degenerating cells; (c) ANT + FL: marked reduction in tubular diameter, absence of step 19 elongated spermatids, note degenerating cells; (d) ANT + FSH $(2 \times 10$ iu): qualitatively normal spermatogenesis, note degenerating cells; (e) ANT + FL + FSH $(2 \times 5$ iu): incomplete spermatogenesis, absence of step 19 elongated spermatids, note degenerating cells; (f) ANT + FL + FSH $(2 \times 10$ iu $)$ : slightly improved spermatogenesis compared with (e), note degenerating cell. AU $\times 350$. 
Table 1. Concentration of serum hormones in male rats treated with vehicle (control), gonadotrophin-releasing hormone antagonist (ANT) alone or in combination with flutamide (FL) and 2 doses of human follicle-stimulating hormone (FSH1 and FSH2) for 2 weeks (Expt 2)

\begin{tabular}{lccccc}
\hline $\begin{array}{l}\text { Treatment } \\
\text { group }\end{array}$ & $\begin{array}{c}\text { hFSH } \\
(\mathrm{iu} / \mathrm{l})\end{array}$ & $\begin{array}{c}\text { rFSH } \\
(\mu \mathrm{g} / \mathrm{l})\end{array}$ & $\begin{array}{c}\text { Inhibin } \\
(\mathrm{U} / \mathrm{l})\end{array}$ & $\begin{array}{c}\text { rLH } \\
(\mu \mathrm{g} / 1)\end{array}$ & $\begin{array}{c}\mathrm{T} \\
(\mathrm{nmol} / \mathrm{l})\end{array}$ \\
\hline Control & $\mathrm{ND}$ & $6 \cdot 1 \pm 0 \cdot 5^{\mathrm{a}}$ & $1020 \pm 17^{\mathrm{a}}$ & $6 \cdot 6 \pm 0 \cdot 9^{\mathrm{a}}$ & $7 \cdot 1 \pm 1 \cdot 3^{\mathrm{a}}$ \\
ANT & $\mathrm{ND}$ & $\mathrm{ND}$ & $623 \pm 2^{\mathrm{b}}$ & $\mathrm{ND}$ & $\mathrm{ND}$ \\
ANT + FSH1 & $12 \cdot 5 \pm 4 \cdot 3^{\mathrm{a}}$ & $4 \cdot 6 \pm 2 \cdot 6^{\mathrm{a}}$ & $660 \pm 11^{\mathrm{b}}$ & $\mathrm{ND}$ & $\mathrm{ND}$ \\
ANT + FSH2 & $18 \cdot 1 \pm 2 \cdot 6^{\mathrm{a}}$ & $6 \cdot 1 \pm 1 \cdot 1^{\mathrm{a}}$ & $983 \pm 41^{\mathrm{a}}$ & $\mathrm{ND}$ & $\mathrm{ND}$ \\
ANT + FL & $\mathrm{ND}$ & $\mathrm{ND}$ & $597 \pm 25^{\mathrm{b}}$ & $\mathrm{ND}$ & $\mathrm{ND}$ \\
ANT + FL + FSH1 & $12 \cdot 5 \pm 2 \cdot 5^{\mathrm{a}}$ & $4 \cdot 8 \pm 1 \cdot 1^{\mathrm{a}}$ & $717 \pm 26^{\mathrm{ab}}$ & $\mathrm{ND}$ & $\mathrm{ND}$ \\
ANT + FL + FSH2 & $19 \cdot 4 \pm 3 \cdot 7^{\mathrm{c}}$ & $9 \cdot 5 \pm 0 \cdot 8^{\mathrm{a}}$ & $878 \pm 72^{\mathrm{ab}}$ & $\mathrm{ND}$ & $\mathrm{ND}$ \\
FL & $\mathrm{ND}$ & $11 \cdot 3 \pm 0 \cdot 8^{\mathrm{c}}$ & $1347 \pm 71^{\mathrm{c}}$ & $49 \cdot 6 \pm 4 \cdot 1^{\mathrm{b}}$ & $67 \cdot 5 \pm 3 \cdot 2^{\mathrm{b}}$ \\
\hline
\end{tabular}

Values are means \pm s.e.m. $(n=7 /$ group). ANT at $450-500 \mu \mathrm{g} / \mathrm{rat}$ per day, $10 \mathrm{mg} \mathrm{FL} / \mathrm{kg}$ per day, FSHl at $2 \times 5 \mathrm{iu} /$ day, FSH2 at $2 \times 10 \mathrm{iu} /$ day. Unlike letters indicate significant difference at $P<0.05$. ND, not detectable (detection limit of assay $1.6 \mathrm{ng} / \mathrm{ml}$ for LH and FSH, $0.87 \mathrm{nmol} / 1$ for testosterone (T), $0.5 \mathrm{iu} / \mathrm{l}$ for $\mathrm{hFSH}$ and $270 \mathrm{U} / \mathrm{l}$ for inhibin).

\section{Discussion}

In the present study, the combination of the antiandrogen flutamide (FL) and ANT greatly enhanced the inhibition by ANT alone on testis size, seminiferous tubule diameter and germ cell development. Since FL is a nonsteroidal, antiandrogen devoid of gestagenic or oestrogenic activity (Neumann \& Töpert, 1986), it is unlikely that the observed effects were caused by a direct effect of FL on germ cells. Flutamide at $10-40 \mathrm{mg} / \mathrm{kg}$ with ANT induced a reduction in testis weight similar to the treatment regimen ANT + EDS. Ethylene dimethane sulphonate is well known in destroying the Leydig cells and, thereby, eliminating the testicular source of testosterone (Morris et al., 1986). Therefore, at $10 \mathrm{mg} / \mathrm{kg}$ (employed subsequently in Expt 2), the antiandrogen FL was probably sufficient to block androgen action.

The marked antigonadotrophic and antispermatogenic actions of ANT are extensively documented in rats (Rivier et al., 1980; Huhtaniemi et al., 1984; Rea et al., 1986; Bhasin et al., 1988; Arslan et al., 1989). In the presence of an antiandrogen, the antispermatogenic effects were much more pronounced. The number of pachytene spermatocytes and step 7 spermatids was 4 times lower compared with treatment with ANT alone. In relation to control testes, there were $\sim 17 \%$ of these cells. Step 19 spermatids had disappeared. In a previous study with the same ANT administered for 30 days, the counts for pachytene spermatocytes and step 7 spermatids were $\sim 30$ and $25 \%$, respectively, of the control (Rea et al., 1986). In contrast to the investigation by Rea et al. (1986), the numbers of A-spermatogonia and preleptotene spermatocytes were also lowered, suggesting that the blockade of androgen action affected all germ cell types of stage VII.

At termination of the present study, the androgen concentrations both in serum and testis were below the detection limit of our assay. Therefore, the additional effects of FL probably became evident in an earlier phase of the experiment, during the first days after initiation of treatments. It is unlikely that ANT was not maximally effective, leading to the additional effects of FL. The same dose of the same ANT suppressed serum gonadotrophin and testosterone concentrations to undetectable levels within 7 days (Chandolia et al., 1991). The ANT ORG 30276, given at a similar daily dose, suppressed serum testosterone concentrations within 7 days (Puente \& Catt, 1986). In monkeys, the ANT used in the present investigation drastically lowered serum testosterone concentrations within 24-48 h (Weinbauer et al., 1984). The effects of EDS in intact rats were observed, within 3 days by the appearance of degenerating germ cells in stage VII tubules (Bartlett et al., 1986). 
The view that the enhanced spermatogenic involution in the presence of FL results from interference with androgen action receives indirect support from the findings of Teerds et al. (1988) and Weinbauer et al. (1989a) that testicular regression was more pronounced in hypophysectomized rats treated with ANT and EDS, although direct effects of EDS on the seminiferous epithelium in adult rat cannot be excluded (Roberts \& Griswold, 1990). Since the antagonistic analogues of gonadotrophin-releasing hormone are considered potential male contraceptives (Weinbauer et al., 1989b), the combination of ANT and antiandrogen could provide an approach for accelerating the onset of spermatogenic suppression.

The data of the present investigation also demonstrate that exogenous FSH increased numbers of germ cells including those of elongated spermatids in ANT-treated rats. Since the experiment lasted only for 2 weeks, it cannot be decided whether the observed effects of FSH represent a true maintenance of the spermatogenic process or whether the spermatogenic involution had been delayed. The supportive effects of testosterone on spermatogenesis in rats (Sun $e t$ al., 1989; Santulli et al., 1990) and monkeys (Marshall et al., 1986) declined with time. In either case, these findings support our previous notion (Bartlett et al., 1989) that FSH is involved in germ cell development in adult rats. Whilst a role of FSH for germ cell development in immature rats (Russell et al., 1987) is well accepted, the involvement of FSH in maintaining spermatogenesis in adult rats has been questioned (Dym et al., 1979). More recently, it was demonstrated that testosterone alone stimulated numbers of germ cells in a quantitative manner (Sharpe et al., 1988; Awoniyi et al., 1989). However, these effects of supranormal testosterone, administered exogenously, do not necessarily prove that, in normal and adult rats, FSH is not involved in the spermatogenic process.

The present data also suggest that the beneficial effects of FSH on numbers of germ cells were less pronounced in the presence of FL. This was particularly evident for the pachytene spermatocytes and round and elongated spermatids. The lower dose of FSH increased the numbers of these germ cells only in the absence of FL. Moreover, although a 2-fold higher FSH dose raised the numbers of round spermatids, the numbers of elongated spermatids were only marginally influenced. It would thus appear that some of the effects of FSH on germ cell evolution are mediated by testosterone. We cannot offer an explanation for this observation. Verhoeven $\&$ Cailleau (1988) reported that androgens and FSH increased the number of androgen receptors on Sertoli cells. Thus, one might speculate that, vice versa, testosterone influences the Sertoli cell FSH receptor. However, hypophysectomy only marginally influenced testicular FSH binding (Seguin $e t$ al., 1981) and ANT administration for 7 days had no effect (Huhtaniemi et al., 1984). On the other hand, FSH stimulated the peripheral concentrations of inhibin in the presence and absence of FL. Because the Sertoli cells are presumably the sole source of inhibin within the seminiferous epithelium and produce inhibin under the influence of FSH (Le Gac \& de Kretser, 1982), a certain responsiveness of the Sertoli cells to FSH was obviously retained. The reduced efficacy of FSH in the presence of FL was most pronounced for the spermatids, in particular the elongated ones. This suggests that the normal development of advanced germ cells requires androgen (Cunningham \& Huckins, 1979; Parvinen, 1982).

From the present study it is concluded that (i) the addition of the antiandrogen FL accelerates ANT-induced testicular involution, (ii) FSH has a role in adult spermatogenesis and (iii) the effects of FSH on advanced germ cells are influenced by androgens.

The technical assistance of R. Sandhowe, E. Langener, M. Heuermann and G. Stelke, the editorial assistance of Dr T. G. Cooper and S. Nieschlag, and the secretarial help of B. Dinkhoff are gratefully acknowledged. We also gratefully acknowledge the gift of GnRH antagonist from $\mathrm{Dr}$ B. H. Vickery (Syntex Research, Palo Alto, CA); flutamide from Essex Pharma, Germany and Schering Corp., NJ, USA; inhibin reagents from Dr D. M. Robertson and Dr D. M. de Kretser (Monash Univ., Melbourne, Australia) and RIA reagents for rLH and rFSH from NIADDK, Bethesda, MD, USA. 


\section{References}

Abercrombie, M. (1946) Estimation of nuclear population from microtome section. Anat. Rec. 94, 238-244.

Arslan, M., Weinbauer, G.R., Khan, S.A. \& Nieschlag, E. (1989) Testosterone and dihydrotestosterone, but not estradiol, selectively maintain pituitary and serum follicle-stimulating hormone in gonadotropinreleasing hormone antagonist treated male rats. Neuroendocrinology. 49, 395-401.

Awoniyi, C.A., Santulli, R., Chandrashekar, V., Schanbacher, B.D. \& Zirkin, B.R. (1989) Quantitative restoration of advanced spermatogenic cells in adult male rats made azoospermic by active immunization against luteinizing hormone or gonadotropinreleasing hormone. Endocrinology. 125, 1303-1309.

Bartlett, J.M.S. Kerr, J.B. \& Sharpe, R.M. (1986) The effect of selective destruction of rat Leydig cells on the intratesticular distribution of testosterone and morphology of the seminiferous epithelium. $J$. Androl. 7, 240-253.

Bartlett, J.M.S., Weinbauer, G.F. \& Nieschlag, E. (1989) Differential effect of FSH and testosterone on the maintenance of spermatogenesis in the adult hypophysectomized rat. J. Endocr. 121, 49-58.

Bhasin, S., Fielder, T., Peacock, N., Sod-Moriah, U.A. \& Swerdloff, R.S. (1988) Dissociating antifertility effects of GnRH-antagonist from its adverse effects on mating behavior in male rats. Am. J. Physiol. 32, E84-E91.

Buhl, A.E., Cornette, J.C., Kirton, K.T. \& Yuan, Y.D. (1982) Hypophysectomised male rats treated with polymethylsiloxane capsules containing testosterone: effect on spermatogenesis, fertility and reproductive tract concentrations of androgens. Biol. Reprod. 27, 369-382.

Chandolia, R.K., Weinbauer, G.F., Behre, H.M. \& Nieschlag, E. (1991) Evaluation of a peripherally selective antiandrogen (Casodex) as a tool for studying the relationship between testosterone and spermatogenesis in the rat. J. steroid Biochem. mol. Biol. 36, 367-375.

Clermont, Y. \& Morgenthaler, H. (1955) Quantitative study of spermatogenesis in the hypophysectomised rat. Am. J. Anat. 57, 369-382.

Cunningham, G.R. \& Huckins C. (1979) Persistence of complete spermatogenesis in the presence of low intratesticular testosterone. Endocrinology. 105, 177-186.

Dym, M., Raj, H.G.M., Lin, Y.C., Chemes, H.E., Kotile, N.J., Nayfeh, S.N. \& French, F.S. (1979) Is FSH required for maintenance of spermatogenesis in adult rats? J. Reprod. Fert., Suppl. 26, 175-181.

Fingscheidt, U., Weinbauer, G.F., Robertson, D.M., de Kretser, D.M. \& Nieschlag, E. (1989) Radioimmunoassay of a male monkey serum inhibin. J. Endocr. 122, 477-483.

Harlin, J., Khan, S.A. \& Diczfalusy, E. (1986) Molecular composition of luteinizing hormone and follicle stimulating hormone in commercial gonadotropin preparations. Fert. Steril. 46, 1055-1061.

Heber, D., Dodson, R., Peterson, M., Channabasavaiah, K.C., Stewart, J.M. \& Swerdlofi, R.S. (1984) Counteractive effects of agonistic and antagon- istic gonadotropin-releasing hormone analogs on spermatogenesis: sites of action. Fert. Steril. 41, 309-313.

Huang, H.F.S., Marshall, G.R., Fleischer, R. \& Nieschlag, E. (1987) Restoration of spermatogenesis by high levels of testosterone in hypophysectomized rats after long term regression. Acta endocr., Copnh. 116, $433-444$.

Huhtaniemi, I.T., Stewart, J.M., Channabasavaiah, K., Fraser, H.M. \& Clayton, R.N. (1984) Effect of treatment with GnRH antagonist, GnRH antiserum and bromocriptine on pituitary-testicular function on adult rats. $M$ ol. Cell. Endocr. 34, 127-134.

Leblond, C.P. \& Clermont, Y. (1952) Definition of the stages of the cycle of the seminiferous epithelium in the rat. Ann. N. Y. Acad. Sci. 55, 548-573.

LeGac, F. \& de Kretser, D.M. (1982) Inhibin production by Sertoli cell cultures. Mol. Cell. Endocr. 28, 487-498.

Marshall, G.R., Jockenhövel, F., Liiedecke, D. \& Nieschlag, E. (1986) Maintenance of complete but quantitatively reduced spermatogenesis in hypophysectomised monkeys by testosterone alone. Acta endocr., Copnh. 113, 424-431.

Morris, I.D., Phillips, D.M. \& Bardin, C.W. (1986) Ethylene dimethane sulphonate destroys Leydig cells in the rat testis. Endocrinology 118, 709-719.

Neumann, F., Töpert, M. (1986) Pharmacology of antiandrogens. J. steroid Biochem. 25, 885-895.

Nieschlag, E., Tekook, W., Usadel, K.H., Kley, K. \& Krüskemper, H.L. (1975) Testicular testosterone concentration and in vitro response to hCG in normal and in testosterone immunized rabbits. Steroids 25 , 379-386.

Parvinen, M. (1982) Regulation of the seminiferous epithelium. Endocr. Rev. 3, 404-417.

Puente, M. \& Catt, K.J. (1986) Inhibition of pituitary gonadal function in male rats by a potent $\mathrm{GnRH}$ antagonist. J. steroid Biochem. 25, 917-925.

Rea, M.A., Marshall, G.R., Weinbauer, G.F. \& Nieschlag, E. (1986) Testosterone maintains pituitary and serum FSH and spermatogenesis in gonadotrophin-releasing hormone antagonist-suppressed rats. $J$. Endocr. 108, 101-107.

Rivier, C., Rivier, J. \& Wale, V. (1980) Antireproductive effects of a potent gonadotropin-releasing hormone antagonist in the male rat. Science, $N Y \mathbf{2 1 0}$, 93-95.

Roberts, K.P. \& Griswold, M.D. (1990) Ethylene dimethane sulphonate inhibits the function of Sertoli cells at sublethal doses. Endocrinology 126, 1618-1622.

Robertson, D.M., Hayward, S., Irby, D., Jacobsen, J., Clarke, C., McLachlan, R.I. \& de Kretser, D.M. (1988) Radioimmunoassay of rat serum inhibin: changes after PMSG-stimulation and gonadectomy. Mol. Cell. Endocr. 58, 1-8.

Russell, L.D. \& Clermont, Y. (1977) Degeneration of germ cells in normal, hypophysectomized and hormone treated hypophysectomized rats. Anat. Rec. 187, 347-366.

Russell, L.D., Alger, L.E. \& Nequin, L.G. (1987) Hormonal control of pubertal spermatogenesis. Endocrinology 120, 1615-1632. 
Santulli, R., Sprando, R.L. Awoniyi, C.A., Ewing, L.L. \& Zirkin, B.R. (1990) to what extent can spermatogenesis be maintained in hypophysectomized adult rat testis with exogenously administered testosterone? Endocrinology 126, 95-102.

Schürmeyer, Th., Wickings, E.J., Freischem, C.W. \& Nieschlag, E. (1983) Saliva and serum testosterone following oral testosterone undecanoate administration in normal and hypogonadal men. Acta endocr., Copnh. 100, 456-462.

Seguin, C., Belanger, A., Cusan, L., Pelletier, G., Reeves, J.J., Lefebrve, F.A., Kelly, P.A. \& Labrie, F. (1981) Relative importance of the adenohypophyseal and gonadal sites of inhibitory action of LHRH agonist. Biol. Reprod. 24, 889-901.

Sharpe, R.M., Bartlett, J.M.S. (1985) Intratesticular distribution of testosterone in rats and the relationship to the concentrations of a peptide that stimulates testosterone secretion. J. Reprod. Fert. 73, 223-236.

Sharpe, R.M., Donachie, K. \& Cooper, I. (1988) Reevaluation of the intratesticular level of testosterone required for maintenance of spermatogenesis in the rat. J. Endocr. 117, 19-26.

Sun, Y.T., Irby, D.C., Robertson, D.M. \& de Kretser, D.M. (1989) The effects of exogenously administered testosterone on spermatogenesis in intact and hypophysectomized rats. Endocrinology 125, 1000-1010.

Teerds, K.J., de Rooij, D.K., Rommerts, F.F.G. \& Wensing, C.J.G. (1988) The regulation of the proliferation and differentiation of Leydig cell precursor cells after EDS administration or daily hCG treatment. J. Androl. 9, 343-351.

Toppari, J., Tsutsumi, I., Bishop, P.C., Parker, J.W., Ahamd, N., Tsang, C., Campeau, J.D. \& diZerega, G.S. (1989) Flow cytometric quantification of rat spermatogenic cells after hypophysectomy and gonadotropin treatment. Biol. Reprod. 40, 623-634.

Verhoeven, G. \& Cailleau, J. (1988) Follicle stimulating hormone and androgens increase the concentration of the androgen receptor in Sertoli cells. Endocrinology 122, 1541-1550.

Weinbauer, G.F., Bolze, P., Bartlett, J.M.S. \& Nieschlag, E. (1989a) Maintenance of rat spermatogenesis by human FSH requires the presence of Leydig cells. Proc. 4th Int. Cong. Androl., Florence, Italy, abstr. p. 48.

Weinbauer, G.F., Khurshid, S., Fingscheidt, U. \& Nieschlag, E. (1989b) Sustained inhibition of sperm production and inhibin secretion induced by a gonadotrophin-releasing hormone antagonist and delayed testosterone substitution in non-human primates (Macaca fascicularis). J. Endocr. 123, 303-310.

Weinbauer, G.F., Surmann, F.J., Akhtar, F.B., Shah, G.V., Vickery, B.H. \& Nieschlag, E. (1984) Reversible inhibition of testicular function by a gonadotropinreleasing hormone antagonist in monkeys (Macaca fascicularis). Fert. Steril. 42, 906-914.

Received 13 August 1990 